\title{
The $\mathrm{X}$ linked recessive form of XY gonadal dysgenesis with a high incidence of gonadal germ cell tumours: clinical and genetic studies
}

\author{
JILLIAN R MANN*, J J CORKERY*, H J W FISHER + , A H CAMERON*, \\ A MAYEROVÁł, U WOLF + , A A KENNAUGH§, AND V WOOLLEYII \\ From*Birmingham Children's Hospital; $\uparrow$ County Hospital, Hereford; \\ $\ddagger$ Institut für Humangenetik und Anthropologie der Universität Freiburg, West Germany; \\ \$Department of Cancer Studies, University of Birmingham; and \\ IIDepartment of Anthropology, University of Durham.
}

SUMMARY Five phenotypic females in one family had the genotype 46,XY and all had gonadal germ cell tumours. Studies of the family pedigree suggest that this form of XY gonadal dysgenesis is inherited in an $\mathrm{X}$ linked recessive manner.

$\mathrm{G}$ banding of elongated metaphase chromosomes from two subjects with XY gonadal dysgenesis and a female carrier showed no aberrations of the $\mathrm{X}$ chromosome. The titres of $\mathrm{H}-\mathrm{Y}$ antigen in three girls with XY gonadal dysgenesis were in the male control range. Thus it appears that, in the $\mathrm{X}$ linked form, $\mathrm{XY}$ gonadal dysgenesis may be caused by a point deletion or mutation of a gene on the $\mathrm{X}$ chromosome, which controls the gonad specific receptor for the $\mathrm{H}-\mathrm{Y}$ antigen.

Studies of $\mathrm{Xg}$ blood groups were uninformative about linkage of $\mathrm{Xg}$ with the $\mathrm{X}$ borne gene causing the $\mathrm{XY}$ gonadal dysgenesis.

Dermatoglyphic studies in the girls with XY gonadal dysgenesis and female carriers revealed high $a-b$ palmar ridge counts and a tendency for the A mainline to terminate in the thenar area. Both of these features have been described in patients with Turner's syndrome.

$\mathrm{XY}$ females with gonadal dysgenesis have streak gonads, ${ }^{1}$ but look like normal females who do not develop secondary sexual characteristics at puberty and do not menstruate. They are chromatin negative and have a 46,XY karyotype. They are usually of normal stature and do not have the somatic stigmata of Turner's syndrome. The affected members of one family $^{2}$ were unusually tall. Sporadic and familial cases are reported and in the latter the mode of inheritance can be either autosomal recessive or $\mathrm{X}$ linked. ${ }^{3-5}$ The basic defects causing the failure of male sex differentiation in these disorders have not been elucidated.

A high incidence of germ cell tumours in streak gonads of patients with the XY karyotype was reported by Taylor et al. ${ }^{6}$

We describe studies in a family in which $X Y$ gonadal dysgenesis appears to have been inherited in an $X$ linked recessive manner, and in which the

Received for publication 17 December 1982 Accepted for publication 30 December 1982. affected members had a very high incidence of gonadal germ cell tumours.

\section{Methods}

CYTOGENETIC STUDIES

Peripheral blood lymphocytes were set up using a standard whole blood technique stimulated with phytohaemagglutinin. Also, for testing certain family members, in order to achieve the high degree of resolution required to detect small interstitial deletions, elongated prometaphase chromosomes were obtained by a thymidine synchronisation procedure based on those of Viegas-Pequignot and Dutrillaux $^{7}$ and Yunis. ${ }^{8}$ The cells were $G$ banded using the method of Herbert. ${ }^{9}$

DETERMINATION OF H-Y ANTIGEN

Anti-H-Y antiserum was raised in isogenic Lewis rats by 6-weekly intraperitoneal injections of $20 \times 10^{6}$ male spleen cells into female animals. The 


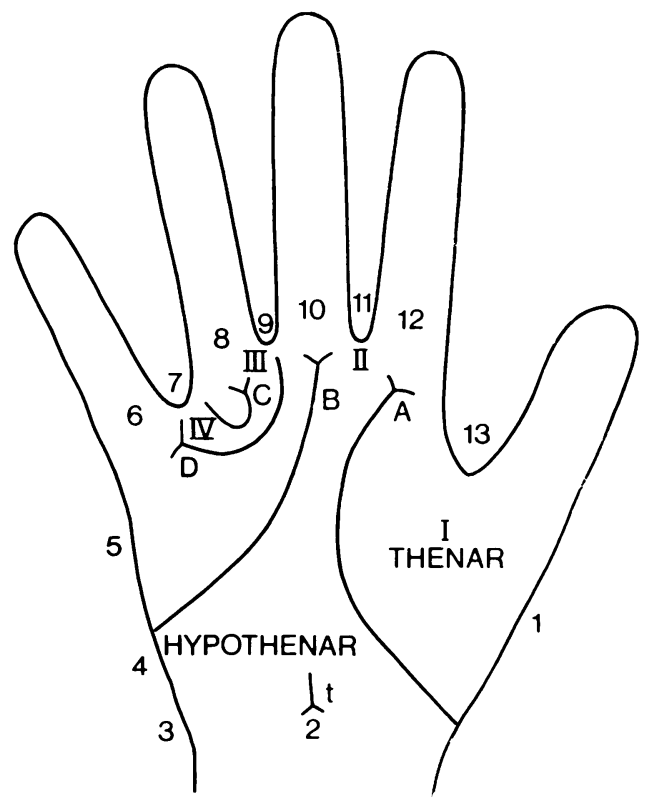

FIG 1 Diagram of palm showing palmar areas and mainlines.

$A, B, C, D$

$I, I I, I I I, I V$

$t$

Numbers $1-13$

Mainlines

Interdigital areas

Axial triradius

Numbering system used to indicate position of mainline terminations

serum was obtained one week after the last injection, inactivated at $56^{\circ} \mathrm{C}$ for 30 minutes, and absorbed with human female $\mathrm{AB}$ erythrocytes, spleen cells of female Lewis rats, and BJAB cells, a female Burkitt lymphoma derived cell line. Of the sera pretreated this way, those showing a clear-cut sex difference in the cytotoxicity test after absorption with male and female control cells respectively were selected for use in the measurements.

Rabbit complement was selected for low cytotoxicity on RAJI male Burkitt lymphoma cells, which served as targets in the cytotoxicity test.

Fibroblasts and buffy coat blood cells from patients and controls were used for absorption and $\mathrm{H}-\mathrm{Y}$ antigen was determined according to the methods of Fellous et al. ${ }^{10}$

\section{BLOOD GROUPING}

Routine serological methods ${ }^{11}$ and the monoclonal antibody $12 \mathrm{E} 7$ to define the polymorphism related to the $\mathrm{Xg}$ groups ${ }^{12}$ were used.

DERMATOGLYPHIC ANALYSIS

The techniques of Penrose and Loesch ${ }^{13}$ were used, incorporating the modifications suggested by Dennis $^{14}$ (see fig 1).

\section{Case report}

The proband (V.27, fig 2) was investigated when aged 13 years for short stature and, like a younger sister (V.29) who was short and of low intelligence and had been investigated previously, was found to have a 46,XY chromosome constitution. When she was 14 years 7 months old she developed abdominal pain and a large mass was found arising in the pelvis and extending to the umbilicus. Her height and weight were both just below the 3 rd centile. She was of dull intelligence and had no breast development and scanty pubic hair. Under anaesthetic the vulva was found to be well-developed and the vagina of normal capacity but the cervix was small and could not be dilated. At laparotomy a huge unresectable tumour arising in the lower pelvic cavity was found and a biopsy was taken. Histological examination

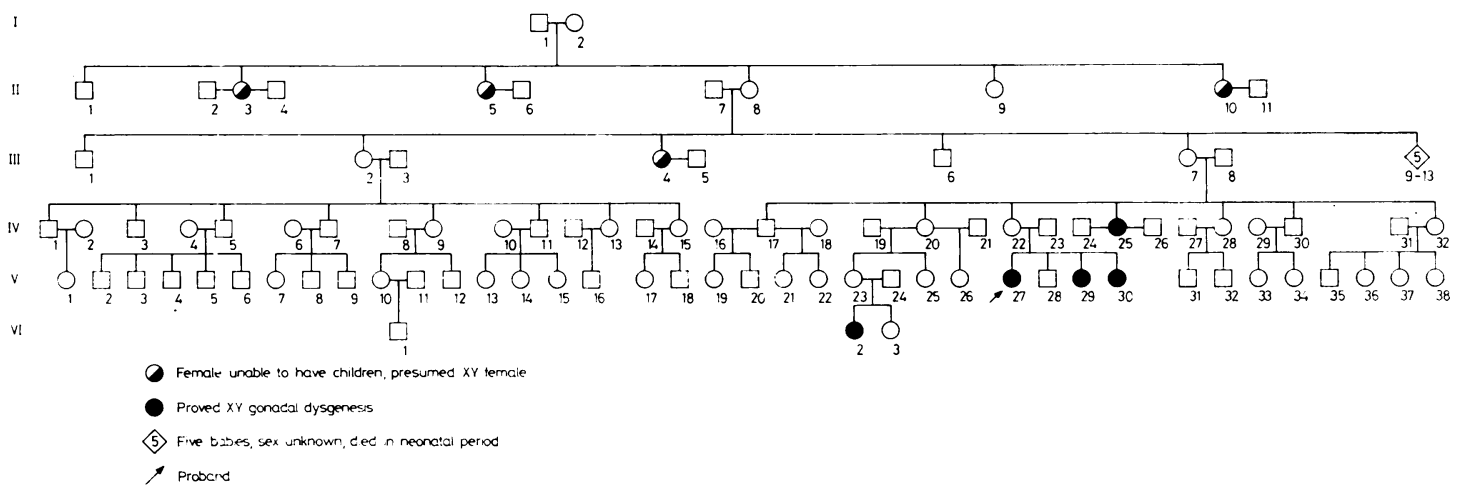

IIG 2 Family pedigree. 
showed a malignant yolk sac tumour having an epithelial appearance, some papillary areas, SchillerDuval bodies, and much necrosis. Many acinar spaces were filled with colloid material and some lining cells contained deeply eosinophilic colloid globules. The secretion was thought to be composed partly of alphafetoprotein (AFP).

Further investigations included serum AFP $28500 \mathrm{U} / \mathrm{ml}, \beta$ human chorionic gonadotrophin ( $\beta$ HCG) $11.0 \mathrm{mIU} / \mathrm{l}$, oestradiol $120 \mathrm{pmol} / \mathrm{l}$, androgens $2 \cdot 8 \mathrm{nmol} / 1, \mathrm{FSH}>50 \mathrm{U} / 1, \mathrm{LH} 48 \mathrm{U} / 1$, normal radiographs of the chest and skeleton, and normal bone marrow aspirate and biopsy.

Substantial regression of tumour and reduction in serum AFP and $\beta$ HCG were achieved with vincristine, actinomycin $D$, and cyclophosphamide and after 11 weeks subtotal excision of a $9 \times 6 \times 6 \mathrm{~cm}$ tumour arising from the right side of the pelvis was performed. The vagina was transected and the uterus and fallopian tubes were removed but no gonads were identified. Histological examination revealed much necrotic tumour, some viable areas consisting of yolk sac tumour, and small areas of well differentiated teratoma containing respiratory epithelium, plain muscle, and glial tissue. No gonad was found, but the tumour probably arose in the right dysgenetic gonad.

Postoperatively the serum AFP levels fell further but never reached normal values despite further chemotherapy and radiotherapy. The patient suffered severe vomiting after her drugs, necessitating dose reductions, and, after one year's chemotherapy, when her condition deteriorated and AFP levels rose, she refused further treatment. She died of tumour recurrence 3 months later. There was no necropsy.

\section{Results of studies on the family members}

After the diagnosis was made in the proband all the available family members were examined and studied. i The family pedigree is shown in fig 2 . It appears that $N$ the condition was inherited in an $X$ linked recessive manner, that is, manifest in XY females but trans- 9 mitted by presumed carrier females. Both of the patient's younger sisters had XY gonadal dysgenesis, so their gonads were removed prophylactically. An aunt (IV.25) had been treated for bilateral 'ovarian' dysgerminomas and we found her chromosomes to be $46, X Y$. Investigation of the family led to the

TABLE 1a Clinical features of subjects with XY gonadal dysgenesis.

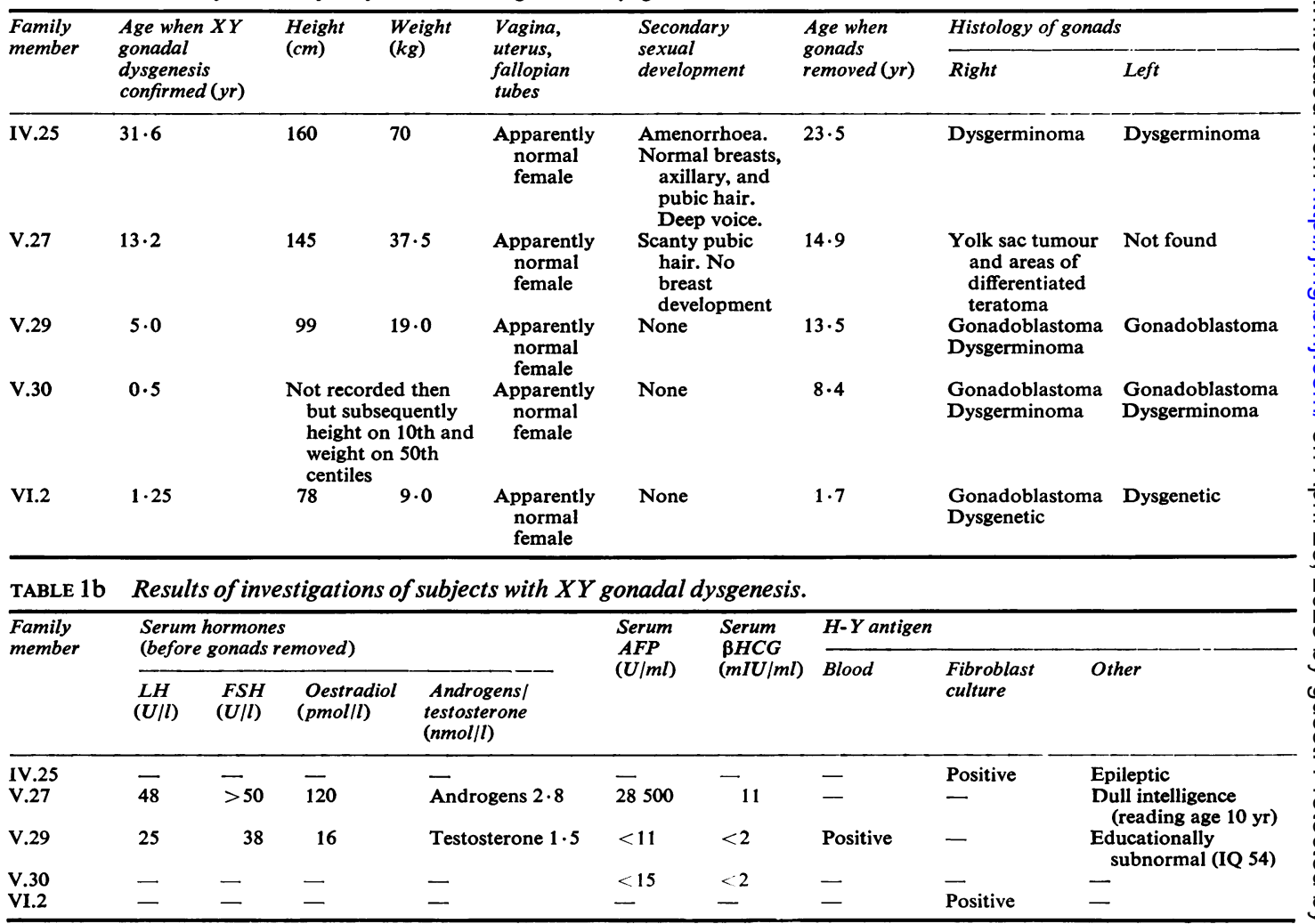


diagnosis of V.12, whose gonads were therefore removed. Further details about the five members proved to have $\mathrm{XY}$ gonadal dysgenesis are shown in table 1. All had gonadal tumours. Four phenotypic females from previous generations were said to have been infertile, but all had died so could not be investigated. One (III.4) was said to have been unusually tall.

\section{CYTOGENETIC STUDIES}

The following phenotypic females were found to be 46,XX: IV.22, V.17, V.25, V.26, V.36, V.37, V.38, VI.3; whereas IV.25, V.27, V.29, V.30, and VI.2 were $46, X Y$.

$\mathrm{G}$ banding on elongated chromosomes from IV.22 (carrier female) and V.29 and V.30 (females with XY gonadal dysgenesis) showed no abnormalities, in particular no deletions in their $\mathrm{X}$ chromosomes.

\section{H-Y ANTIGEN}

The results of the determinations of $\mathrm{H}-\mathrm{Y}$ antigen on three subjects with XY gonadal dysgenesis (IV.25, V.29, and VI.2) are shown in fig 3. All had titres in the male control range.

\section{BLOOD GROUPING}

All the family members tested (IV.20, IV.22, IV.23, IV.25, IV.32, V.17, V.23, V.25, V.27, V.29, V.30,
V.36, V.37, V.38, VI.2, VI.3) were $\mathrm{Xg}(\mathrm{a}+)$. The cells of all these relatives were also tested and found positive with the monoclonal antibody $12 E 7^{12}$ defining the polymorphism related to the $\mathrm{Xg}$ blood groups. Results for 12 other blood group systems are available on request.

\section{DERMATOGLYPHIC CHARACTERISTICS}

Four subjects with $\mathrm{XY}$ gonadal dysgenesis, three obligatory carriers, six other blood relatives, and three relatives by marriage were studied. No abnormal patterns were seen in their fingers or palms (tables 2 and 3). In IV.20 the relatively uncommon radial hypothenar arch pattern was present on the right hand and IV.32 had a displaced axial triradius on the right hand, though no true arch was formed.

The formulae for the mainline endings are included in table 3. There was a tendency for the A mainline to terminate in area 1 , the thenar area, especially in the XY gonadal dysgenesis subjects and their mothers. The $B$ mainline showed a tendency to terminate in area 5. The C and D mainlines showed no trends, although there were four instances of a missing $C$ triradius giving an $\mathrm{O}$ termination for the $\mathrm{C}$ mainline.

The palmar ridge counts are given in table 4 . The $a-b$ ridge counts, particularly for the left hand, were higher for the $\mathrm{XY}$ gonadal dysgenesis subjects

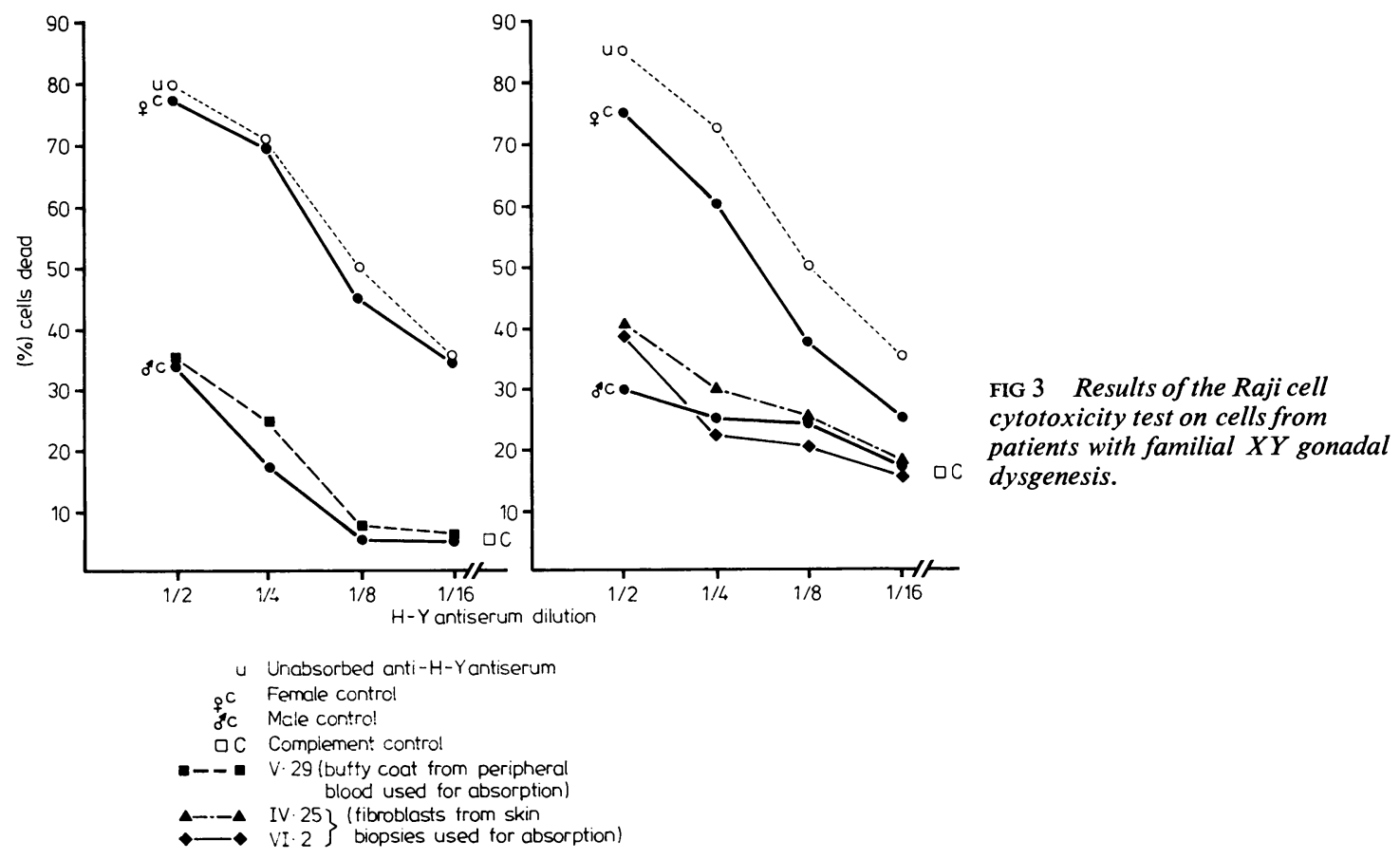


TABLE 2 Digital patterns.

\begin{tabular}{|c|c|c|c|c|c|c|c|c|c|c|c|}
\hline \multirow[t]{2}{*}{ Suhiect } & & \multicolumn{5}{|c|}{ Right hand } & \multicolumn{5}{|c|}{ Left hand } \\
\hline & & 1 & 2 & 3 & 4 & 5 & 1 & 2 & 3 & 4 & 5 \\
\hline \multirow[t]{4}{*}{$\mathrm{XY}$ gonadal dysgenesis } & IV. 25 & $\mathrm{dl}$ & Iu & $\mathrm{I}^{\mathrm{u}}$ & $\mathrm{l}^{\mathbf{u}}$ & $j^{u}$ & $\mathrm{ju}^{\mathrm{u}}$ & $\mathrm{l}^{\mathrm{u}}$ & $\mathrm{j}^{\mathrm{u}}$ & $\mathrm{l}^{\mathrm{u}}$ & ju \\
\hline & V.29 & $1^{u}$ & $j^{u}$ & $\mathrm{j}^{\mathrm{u}}$ & ju & $j^{u}$ & $j^{u}$ & $\mu^{u}$ & $\mathbf{1}^{r}$ & $j^{u}$ & $j^{u}$ \\
\hline & V.30 & $j^{u}$ & $j^{u}$ & $1^{u}$ & $1^{u}$ & $\mathrm{j}^{\mathrm{u}}$ & ju & $\mathrm{j}^{\mathrm{u}}$ & $\mathrm{j}^{\mathrm{u}}$ & $\mathrm{j}^{\mathrm{u}}$ & $j^{u}$ \\
\hline & VI.2 & $\mathrm{j}^{\mathrm{u}}$ & $\mathrm{l}^{\mathrm{r}}$ & $\mathbf{w}$ & w & ju & ju & w & w & w & ju \\
\hline \multirow[t]{3}{*}{ Obligatory carriers } & IV.20 & $j^{u}$ & $\mathrm{j}^{\mathbf{u}}$ & $\mathrm{ju}^{\mathrm{u}}$ & $\mathrm{j}^{\mathrm{u}}$ & $\mathrm{j}^{\mathrm{u}}$ & $j^{u}$ & $\mathrm{j}^{\mathrm{u}}$ & $\mathbf{j}^{\mathbf{u}}$ & $\mathrm{j}^{\mathrm{u}}$ & ju \\
\hline & IV. 22 & $j^{u}$ & $\mathrm{j}^{\mathrm{u}}$ & ju & $\mathrm{ju}^{\mathrm{u}}$ & $j^{u}$ & ju & $j^{u}$ & $\mathrm{ju}^{\mathrm{u}}$ & $\mathrm{ju}^{\mathrm{u}}$ & $j^{u}$ \\
\hline & V.23 & dl & $w$ & w & dl & $1^{u}$ & ju & $\mathrm{j}^{\mathrm{u}}$ & $\mathrm{dl}$ & dl & dl \\
\hline \multirow[t]{6}{*}{ Other blood relatives } & V. 25 & $\mathrm{l}^{\mathrm{u}}$ & $\mathbf{l}^{\mathbf{r}}$ & $\mathbf{A}$ & $\mathrm{I}^{\mathrm{u}}$ & $j^{u}$ & $\mathrm{I}^{\mathrm{u}}$ & $\mathbf{A}$ & $\mathbf{A}$ & $1^{u}$ & $1^{u}$ \\
\hline & V. 26 & $w$ & $j^{u}$ & $\mathrm{ju}^{\mathrm{u}}$ & $j^{u}$ & $w$ & $\mathrm{dl}$ & $j^{u}$ & $\mathrm{ju}^{\mathrm{u}}$ & Iu & w \\
\hline & V.32 & dl & $j^{u}$ & $j^{u}$ & ju & $j^{u}$ & $\mathrm{I}^{\mathrm{u}}$ & $j^{u}$ & $\mathrm{j}^{\mathrm{u}}$ & $\mathrm{l}^{\mathrm{u}}$ & $1^{u}$ \\
\hline & V.36 & $w$ & $j^{u}$ & $\mathrm{j}^{\mathrm{u}}$ & w & $j^{u}$ & $j^{u}$ & $j^{u}$ & $j^{u}$ & w & ju \\
\hline & V.37 & dl & ju & ju & $w$ & $j^{u}$ & dl & $j^{u}$ & dl & $\mathbf{w}$ & $j^{u}$ \\
\hline & V.38 & dl & dl & $j^{u}$ & - & - & - & - & - & - & - \\
\hline \multirow{2}{*}{ Non-blood relatives } & IV.23 & $\mathrm{lu}^{\mathrm{u}}$ & $\mathrm{ju}$ & $\mathrm{j}^{\mathrm{r}}$ & $j^{u}$ & $\mathrm{j}^{\mathrm{u}}$ & $j^{u}$ & $w$ & $\rho^{u}$ & $\mathrm{l}^{\mathrm{u}}$ & $j^{u}$ \\
\hline & V.24 & $j^{u}$ & $\mathrm{l}^{\mathrm{r}}$ & $\mathfrak{j}^{\mathbf{u}}$ & $j^{u}$ & ju & ju & $\mathrm{ju}^{\mathrm{u}}$ & ju & $w$ & $\mathrm{ju}^{\mathrm{u}}$ \\
\hline
\end{tabular}

$\mathrm{A}=\operatorname{arch}, \mathrm{l}^{\mathrm{u}}=\mathrm{ulnar}$ loop, $\mathrm{l}^{\mathrm{r}}=$ radial loop, $\mathrm{dl}=$ double loop, $\mathrm{w}=$ whorl.

TABLE 3 Palmar patterns and mainline endings.

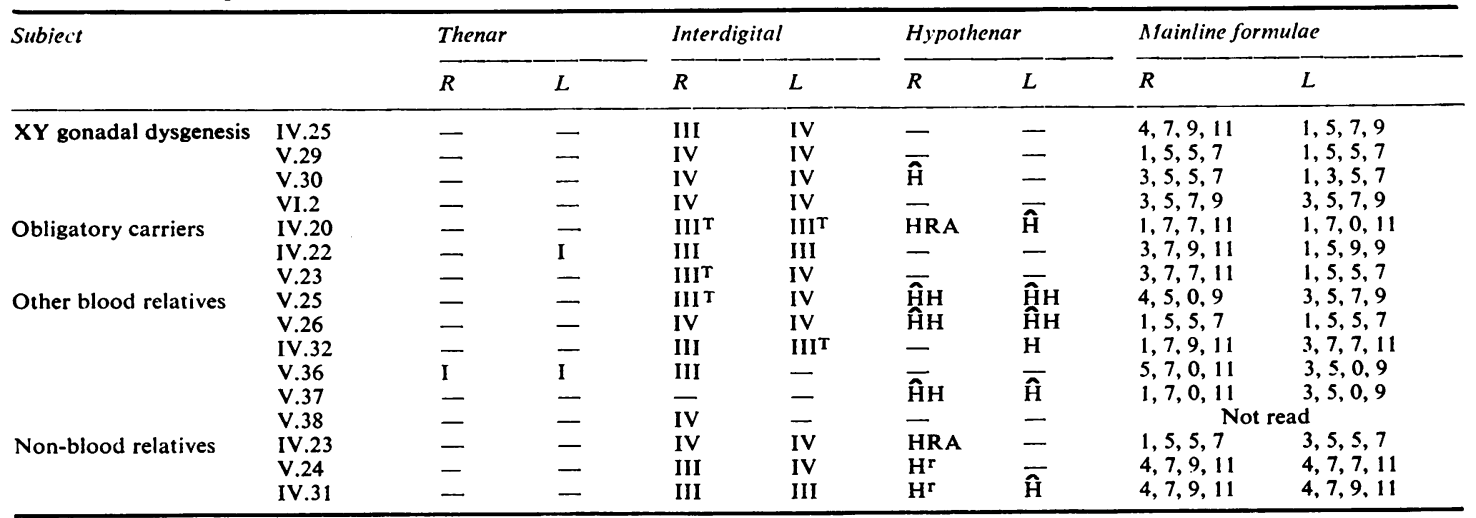

$I=$ peripheral thenar loop, IIIT = tented arch in 3rd interdigital area, $H=$ hypothenar peripheral loop, HRA=hypothenar radial arch, III, IV $=$ peripheral loops in interdigital areas, $\hat{i}=$ hypothenar central loop, $\mathrm{H}^{\mathrm{r}}=$ hypothenar radial loop.

TABLE 4 Palmar ridge counts.

\begin{tabular}{|c|c|c|c|c|c|c|c|c|c|c|}
\hline \multirow[t]{2}{*}{ Subiect } & & \multicolumn{4}{|c|}{ Right } & \multicolumn{5}{|l|}{ Left } \\
\hline & & $a-b$ & $b-c$ & $c-d$ & $R T O T$ & $a-b$ & $b-c$ & $c-d$ & LTOT & $T P R C$ \\
\hline \multirow[t]{4}{*}{$X Y$ gonadal dysgenesis } & IV.25 & 39 & 27 & 34 & 100 & 50 & 23 & 38 & 111 & 211 \\
\hline & V.29 & 53 & 34 & 44. & 131 & 57 & 26 & 47 & 130 & 261 \\
\hline & V.30 & 49 & 41 & 48 & 138 & 60 & 38 & 49 & 147 & 285 \\
\hline & VI.2 & 42 & 20 & 36 & 98 & 48 & 19 & 34 & 101 & 199 \\
\hline \multirow[t]{3}{*}{ Obligatory carrier } & IV. 20 & 39 & 17 & 45 & 101 & 42 & 20 & 43 & 105 & 206 \\
\hline & IV.22 & 58 & 32 & 45 & 135 & 62 & 36 & 45 & 143 & 278 \\
\hline & V.23 & 40 & 24 & 39 & 103 & 41 & 28 & 34 & 103 & 206 \\
\hline \multirow[t]{6}{*}{ Other blood relatives } & V.25 & 34 & 26 & 33 & 93 & 45 & 18 & 36 & 99 & 192 \\
\hline & V.26 & 32 & 23 & 36 & 91 & 43 & 21 & 33 & 97 & 188 \\
\hline & IV.32 & 36 & 30 & 30 & 96 & 44 & 22 & 37 & 103 & 199 \\
\hline & V.36 & 42 & 26 & 26 & 94 & 43 & $\ldots 60$ & $\ldots$ & 103 & 197 \\
\hline & V.37 & 46 & $\ldots$ & $\ldots$ & 85 & 38 & $\ldots 38$ & $\ldots$ & 76 & 161 \\
\hline & V.38 & 38 & 27 & 17 & 80 & \multicolumn{3}{|c|}{ No ridge count } & 一 & - \\
\hline \multirow[t]{3}{*}{ Non-blood relatives } & IV.23 & 38 & 38 & 40 & 116 & 42 & 38 & 40 & 120 & 236 \\
\hline & V.24 & 44 & 23 & 34 & 101 & 44 & 20 & 34 & 98 & 199 \\
\hline & IV.31 & 39 & 21 & 35 & 95 & 45 & 18 & 32 & 95 & 190 \\
\hline
\end{tabular}


and for the obligatory carriers than for the unaffected female relatives. These $a-b$ ridge counts affected the total palmar ridge counts, which were consequently higher in the affected members of the family.

\section{Discussion}

The presence of the $\mathrm{H}-\mathrm{Y}$ antigen appears to be essential for the organisation of the mammalian testis, and the structural gene for $\mathrm{H}-\mathrm{Y}$ antigen is believed to be autosomal. ${ }^{15}$ Production of the antigen is thought to be regulated by genes on the $Y$ chromosome, whereas genes on the $\mathrm{X}$ chromosome have a suppressing effect. The $\mathrm{X}$ chromosome also appears to possess a gene for a gonad specific receptor for $\mathrm{H}-\mathrm{Y}$ antigen ${ }^{15}$ without which the virilising effects of the antigen are not expressed.

Studies in the Scandinavian wood lemming have assisted the understanding of the interaction between the genes involved in sex determination. In this species two morphologically different $\mathrm{X}$ chromosomes exist, $\mathrm{X}$ and $\mathrm{X}^{*}$. The $\mathrm{X}^{*}$ chromosome is slightly shorter than the wild type $X$, presumably owing to a deletion in the short arm. ${ }^{16}$ The $\mathrm{X}^{*}$ chromosome is generally correlated with a female phenotype, even in the presence of a $Y$ chromosome, only $X Y$ animals showing a male phenotype $\left(X^{*} X Y\right.$ subjects, showing a phenotypic range from male to female, will not be discussed here). Other genotypes which occur in wood lemmings, $\mathrm{XX}, \mathrm{X}^{*} \mathrm{Y}, \mathrm{X}^{*} \mathrm{O}$, $\mathrm{X}^{*} \mathrm{X}$, and $\mathrm{XO}$, are all fertile females. An area on the short arm (deleted in the $\mathrm{X}^{*}$ genotypes) appears to contain the gene for the gonad specific receptor of the $\mathrm{H}-\mathrm{Y}$ antigen (and also for its suppressor)..$^{1517}$

In the family we report the genetic situation resembles that of the $X^{*} Y$ wood lemming female, that is, the autosomally mediated production of $\mathrm{H}-\mathrm{Y}$ antigen is normal because the regulatory gene on the $\mathrm{Y}$ chromosome is functioning, but the $\mathrm{X}$ chromosome lacks the presumed gonad specific receptor gene, so differentiation of the testis does not occur. The affected subjects thus develop as females but, unlike the $X^{*} Y$ lemming, have dysgenetic gonads and are not fertile. This parallels the XO condition resulting in fertile females in rodents, but in sterile females with dysgenetic gonads in the human. Subject IV.25 in our pedigree, however, had spontaneous breast development, but never menstruated.

The analogy with the $X^{*} Y$ wood lemming would have been strengthened had we been able to demonstrate a deletion on the $\mathrm{X}$ chromosome of our patients and the obligatory carriers who were tested. However, we cannot exclude the presence of a point mutation or deletion.

Previous studies of $\mathrm{H}-\mathrm{Y}$ antigen in $\mathrm{XY}$ gonadal dysgenesis have involved mostly sporadic cases, and familial occurrence only in sibs of one generation, and some showed normal titres whereas others did not. ${ }^{18}$ Thus there appears to be genetic heterogeneity in the disorder and the precise mechanisms involved are not yet fully understood for all the variants.

The $\mathrm{H}-\mathrm{Y}$ suppressor gene in man seems to be closely linked to the loci on Xp22.3 $\rightarrow$ Xpter required for the expression of steroid sulphatase and the $\mathrm{Xg}$ blood group antigen. ${ }^{19-21}$ Since, in the wood lemming, the suppressor gene and the receptor gene appear to be affected by the same deletion, they should be in close proximity. If this linkage group was conserved in evolution, the receptor gene should be close to Xp22.3 in the human. However, all the family members tested were $\mathrm{Xg}(\mathrm{a}+)$ and therefore uninformative about linkage with the $\mathrm{X}$ borne gene causing gonadal dysgenesis.

It has become apparent that the only subjects with intersex states who are particularly prone to gonadal tumours are those with a $\mathrm{Y}$ chromosome line. ${ }^{22}$ Thus, there is little increased risk in girls with $45, \mathrm{XO}$ Turner's syndrome whereas the risk for gonadoblastoma or dysgerminoma, arising usually in the second and third decade, had been estimated to be in the order of 20 to $30 \%$ for $45, \mathrm{XO} / 46, \mathrm{XY}$ mosaics (male intersex with Turner phenotype) and girls with $\mathrm{X}$ linked gonadal dysgenesis. ${ }^{22}$ Gonadal tumours are rare in true hermaphrodites but an increased risk of perhaps $10 \%$ is present in karyotype $46, \mathrm{XY}$ testicular feminisation subjects. Tumours have been described in XY gonadal dysgenesis as early as 7 years of age. ${ }^{23}$ Gonadal tumours in girls with $X Y$ gonadal dysgenesis who express the $\mathrm{H}-\mathrm{Y}$ antigen have been reported and it has been postulated that $\mathrm{H}-\mathrm{Y}$ negative subjects may have a lower risk of tumours. ${ }^{5}$ However, further pedigrees of $\mathrm{H}$-Y negative cases have not yet been studied to establish whether this is so.

As reported in another study, ${ }^{24}$ the dermatoglyphic prints revealed no abnormalities in the finger or palm patterns. However, in the girls with XY gonadal dysgenesis and in female carriers there were high $a-b$ palmar ridge counts and a tendency for the $\mathrm{A}$ mainline to terminate in the thenar area. Both of these features have been described as characteristics of patients with Turner's syndrome, ${ }^{25}$ but further studies are needed to clarify this possible similarity in the features present in XY and XO dysgenesis.

We thank Miss A G Thomson, Mrs D E Butler, and Mrs S M Bowser-Riley for cytogenetic studies, Miss H Johnston and Mrs P Dilworth for taking the palm prints, Professor D G Harnden for advice and for performing fibroblast cultures, Dr $\mathbf{J}$ Insley for advice, Dr R Sanger and the staff of the MRC Blood 
Group Unit for the blood group studies, and Mrs K Evans for typing the manuscript.

Reference to the results of the determination of $\mathrm{H}-\mathrm{Y}$ antigen in the subjects with $\mathrm{XY}$ gonadal dysgenesis has been published previously. ${ }^{15} 17$

\section{References}

1 McKusick VA. Mendelian inheritance in man. 5th ed. Baltimore: Johns Hopkins University Press, 1978:759.

2 Espiner EA, Veale AM, Sands VE, Fitzgerald PH. Familial syndrome of streak gonads and normal male karyotype in five phenotypic females. $N$ Engl $\mathrm{J}$ Med 1970;283:6-11.

3 Simpson JL, Christakos AC, Horwith M, Silverman FS. Gonadal dysgenesis in individuals with apparently normal chromosomal complements: tabulation of cases and compilation of genetic data. Birth Defects 1971;7:215-28.

4 German J, Simpson JL, Chaganti RSK, Summitt RL, Reid LB, Merkatz JR. Genetically determined sexreversal in 46,XY humans. Science 1978 ;202:53-6.

5 Simpson JL, Blagowidow N, Martin AO. XY gonadal dysgenesis: genetic heterogeneity based upon clinical observations, $\mathrm{H}-\mathrm{Y}$ antigen status and segregation analysis. Hum Genet $1981 ; 58: 91-7$.

6 Taylor H, Barter RH, Jacobson CB. Neoplasms of dysgenetic gonads. Am J Obstet Gynecol 1966;96:816-23.

7 Viegas-Pequignot E, Dutrillaux B. Une méthode simple pour obtenir des prophases et des prométaphases. Ann Genet (Paris) 1978;21:122-5.

8 Yunis JJ. High resolution chromosomes. Science 1976; $191: 1268-70$.

9 Herbert A. High resolution banding of prometaphase chromosomes. Hum Genet 1982;61:63-4.

10 Fellous M, Günther E, Kemler R, et al. Association of the $\mathrm{H}-\mathrm{Y}$ male antigen with $\beta_{2}$-microglobulin in human lymphoid and differential mouse teratocarcinoma cell lines. J Exp Med 1978;148:58-70.

11 Race RR, Sanger R. Blood groups in man. 6th ed. Oxford, London: Blackwell, 1975.

12 Goodfellow PN, Tippett P. A human quantitative polymorphism related to $\mathrm{Xg}$ blood groups. Nature $1981 ; 289$ :404-5.

13 Penrose LS, Loesch D. Topological classification of palmar dermatoglyphics. J Ment Defic Res 1970;14: 111-28.

14 Dennis RLH. Dermatoglyphic studies. Dyn. The Journal of the Durham University Anthropological Society 1977; 4:1-60.

15 Wiberg V, Mayerová A, Muller U, Fredga K, Wolf U. $\mathrm{X}$-linked genes of the $\mathrm{H}-\mathrm{Y}$ antigen system in the wood lemming (Myopus schisticolor). Hum Genet 1982;60: 163-6.

${ }_{16}$ Herbst EW, Fredga K, Frank F, Winking H, Gropp A. Cytological identification of two X-chromosome types in the wood lemming (Myopus schisticolor). Chromosoma $1978 ; 69: 185-91$.

17 Wolf $\mathrm{U}$. The H-Y antigen system: interaction of several genes in gonadal differentiation. International Congress Series No 559. Development and function of reproductive organs. In: Byskov AG, Peters H, eds. Proceedings of the $V$ th workshop on the development and function of the reproductive organs, Copenhagen 1981. Amsterdam: Excerpta Medica, $1981: 260-3$.

18 Wolf U. XY gonadal dysgenesis and the $\mathrm{H}-\mathrm{Y}$ antigen. Hum Genet 1979;47:269-77.

19 Shapiro LJ, Mohandas T, Weiss R, Romero G. Nonactivation of an X-chromosome locus in man. Science 1979;204:1224-6.

20 Wolf U, Fraccaro M, Mayerová A, Hecht T, Zuffardi O, Hameister $\mathrm{H}$. Turner syndrome patients are $\mathrm{H}-\mathrm{Y}$ positive. Hum Genet 1980;54:315-8.

21 Tiepolo L, Zuffardi O, Fraccaro M, et al. Assignment by deletion mapping of the steroid sulfatase $X$ linked $\infty$ ichthyosis locus to Xp223. Hum Genet 1980;54:205-6.

22 Schimpke RN. Genetics and cancer in man. Edinburgh: Churchill Livingstone, 1978: 80-2.

23 Isurugi $\mathrm{K}$, AsoY, Ishida $\mathrm{H}$, et al. Prepubertal XY gonadal dysgenesis. Pediatrics 1977;59:569-73.

24 Chemke J, Carmichael R, Stewart JM, Geer RH, Robinson A. Familial XY gonadal dysgenesis. J Med $\mathbb{D}$ Genet 1970;7:105-11.

25 Schaumann B, Alter M. Dermatoglyphics in medical $\overrightarrow{\bar{O}}$ disorders. New York: Springer-Verlag, 1976:174-7.

Correspondence and requests for reprints to Dr J R Mann, The Children's Hospital, Ladywood Middleway, Birmingham B16 8ET. 